\title{
Field Ion Microscopic Observation of Precipitate Phase in $\mathrm{Fe}-\mathrm{Cr}$ Alloy
}

$$
\text { F e - C r 合金中の析出相の F I M よる観察 }
$$

Kunihiro Komori, Masanobu Namita and Tsunenori Suzuki Department of Physics, Faculty of Science, Tokai University

1117 Kitakaname, Hiratsuka, Kanagawa, 259-12 Japan

( Accepted for publication 17 November 1994 )

\section{1. 緒言}

$\mathrm{Fe}-\mathrm{Cr}$ 合金の過的和固溶体を、500 $\mathrm{C}$ 以下で時效処理を すると、Crの富んだ $\alpha^{\prime}$ 相とCrのFeの富んだ $\alpha$ 相に 2 相 分離をする事が知られている。Fe-32at\%Cr合金での分離 過程は、スピノーダル型が主であると報告されている。 しかしながら、Fe-Cr合金系には编析が生じやすい等、 複雑な系であるため、その相分雎逻程はあまり明確では ない。本研究では、原子レベルで原子配列が制測出来る 電界イオン影微鏡(FIM)を用い, Fe-Cr合金の極微細な原 子配列状態を決定し、その相分噰過程を解明するもので ある。今回は $\mathrm{Fe}-\mathrm{Cr}$ 合金中の相分噰過程で観测される FIM 像についての知見を得ることを目的とした。そのた め、コンピュータシミュレーションを行い、Fe-Cr 合金 の FIM像について解析を行つた。

\section{2 . 実験方法}

$\mathrm{Fe}-30 \mathrm{at} \% \mathrm{Cr}$ の合金をArガス中で $1100^{\circ} \mathrm{C}$ で 5洔閒溶体 処理を行い、水水中に烧き入れた。試料の厚さを約 0 . $1 \mathrm{~mm}$ に切り出し $470^{\circ} \mathrm{C}$ で98時間と283時間の時効処理を行 つた。それぞれについてFIMで觀察を行つた。FIMはステ ンレス製の装置で、到達真空度は5.0 $010^{-10} \mathrm{Torr}$ である。 3.結果・考察

Figure 1にFe-30at\$Crを470 Cで98時間時効処理した FIM像を示す。Fe-Cr合金でのFIM像は選択的イオン化あ るいは選択的菓界蒸発によりFe原子の部分が輝点として 観測される。98時間処理した試料のFIM像には明るく大 きな輝点が存在する部分があり、明るい辈点は2つの対 として観测された。しかしながらリング状の面は観测さ れないため原子配列の詳細については明らかではない。

一方暗くわずかに輝点が存在する部分も上方に筧测さ れた。この結果から98時間時效の合金中にFeの富んだ部 分とCrの富んだ部分が存在すると考えられる。そのコン ピュータシミュレーションをFig.2に示す。シミュレー ションでは輝点が $\mathrm{Fe}$ 原子を表している。点が多い部分と 少ない部分が観测されると Fig.1の様なコントラストの 強い像として現れる。また、C.J.DalzellはFe-32atXCr を $470^{\circ} \mathrm{C} て ゙$ 時效し、アトムプローブ分析を行つた。193時 間の短時間の試料では濃度ゆらぎの波長は長くなり、そ の後669時間時効で一度波長が短く、更に時効を続ける と濃度ゆらぎの波長が長くなると報告している1。本研 究の98時間時効でもFe-Crの初期の濃度ゆらぎが存在し ている。Fig.3に283時間時効したFIM像を示す。283時間
時効のFIM像では輝点が全体に钼测された。更に明るい 輝点の集合も存在している。この事から初期の濃度ゆら ぎが減少する復元過程があり、その後、相分離遇程に移 ると思われる。Fe-Cr合金の相分離過程を研究するには、 最初の過飽和固溶体での初期の惯度ゆらぎを検討する必 要がある。

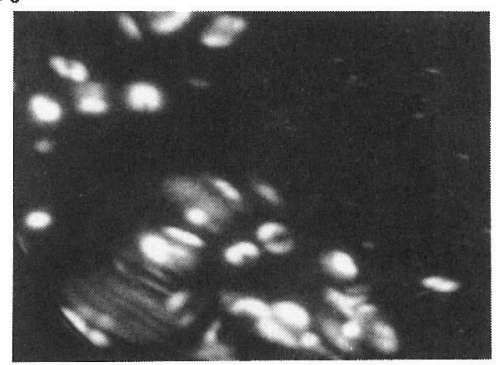

Fig.1 Fe-30at\%Crを $470^{\circ} \mathrm{C}$ で98時間時効FIM像

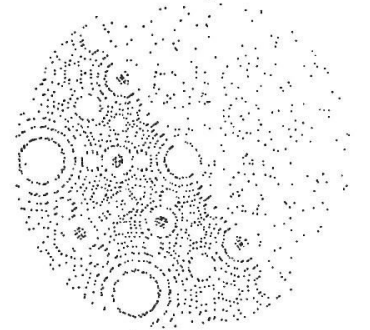

Fig.2 Fig.1のコンピュータシミュレーション 左半分はFeが右半分は $20 \mathrm{at} \%$ 濃度である。

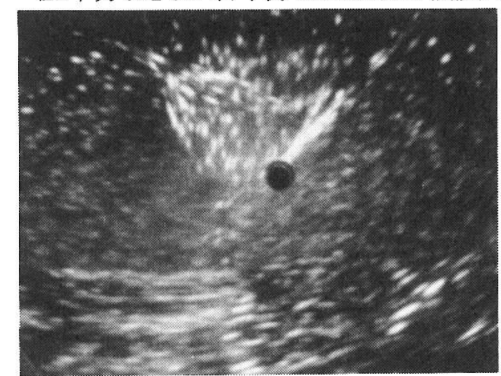

Fig.3 Fe-30atCrを470 ${ }^{\circ} \mathrm{C} て ゙ 283$ 時間時効FIM像 4 . 参考文献

C.J.Dalzell, J.De.Physique, 49.C6-411(1988).

194 SAS Intelligent Symposium 